\title{
AN ANALYSIS ON GRAMMATICAL ERRORS IN STUDENTS' RECOUNT TEXTS: A CASE STUDY ON THE SECOND GRADE STUDENTS FACULTY OF LETTERS INDRAPRASTA PGRI UNIVERSITY
}

\author{
Sugianti Somba* \\ English Education Department, Indraprasta PGRI University \\ Received on 3 July 2017 / Approved on 25 September 2017
}

\begin{abstract}
This study aims to analyze and classify what types of mistakes made by learners (in this case the second grade students of Indraprasta University PGRI) in applying the simple past tense in the text of recount text. The errors are defined according to Mariusz Trawinski's theory. In addition, this study aims to obtain percentage of each type of mistakes made by learners, as well as to uncover the most dominant mistakes made by learners in using the simple past tense in the text recount. The method used in this research is descriptive qualitative method, while the general pattern or research design used by the researcher is a case study. Furthermore, the authors chose the second level of students who numbered 25 people as subjects in this study. The data in this research is obtained through the test of making recounts to the students. The result of the error analysis process is that learners perform three types of errors which are regular verb, irregular verbs, and auxiliary verbs. It is seen from the percentage of each type of error, the auxiliary verb is the most commonly performed error type with a percentage of $42.23 \%$. Furthermore, errors in irregular verb is $33.90 \%$, whereas the type of regular verb error is $29.87 \%$ of the total errors made by the learner. And from the side of the taxonomy of surface tactics or surface strategy taxonomy, errors in regular verb, irregular verb, and to be auxiliary consist of misformation, misordering, omission, and addition error. The highest error on auxiliary verb is misformation. The highest error on irregular verb is misformation. And the highest error in regular verb is omission. This shows that the use of simple past tense in writing recount text is still difficult to understand the students of the second grade of PGRI Indraprasta University.
\end{abstract}

Keywords: simple past, recount texts

\section{ABSTRAK}

Penelitian ini bertujuan untuk menganalisis dan mengelompokkan jenis-jernis kesalahan apa saja yang dilakukan oleh peserta didik (dalam hal ini mahasiswa tingkat kedua Universitas Indraprasta PGRI) dalam menerapkan the simple past tense dalam tulisan teks recount. Kesalahan-kesalahan tersebut dikelompokkan berdasarkan teori Mariusz Trawinski. Selain itu, penelitian ini bertujuan untuk memperoleh persentasi dari setiap jenis kesalahan yang dilakukan oleh peserta didik, serta untuk mengungkap kesalahan-kesalahan yang paling dominan yang dilakukan oleh peserta didik dalam menggunakan the simple past tense dalam tulisan teks recount. Metode yang digunakan dalam penelitian ini adalah metode deskriptif kualitatif, sedangkan pola umum atau rancangan penelitian yang digunakan oleh peneliti adalah studi kasus. Selanjutnya, penulis memilih peserta didik tingkat kedua yang berjumlah 25 orang sebagai subjek dalam penelitian ini. Data dalam penelitian ini diperoleh melalui tes membuat karangan recount kepada peserta didik. Hasil dari proses error analysis adalah peserta didik melakukan tiga jenis kesalahan yaitu kesalahan penggunaan kata kerja beraturan, kata kerja tidak beraturan, dan kata kerja bantu. Dilihat dari presentase setiap jenis kesalahan, kata kerja bantu (auxiliary verb) merupakan jenis kesalahan yang paling sering dilakukan dengan presentase sebesar 42,23\%. Selanjutnya, kesalahan pada penggunaan kata kerja tidak beraturan (irregular verb) sebesar 33,90\%, sedangkan jenis kesalahan kata kerja beraturan yaitu sebesar 29,87\% dari total kesalahan yang dilakukan oleh peserta didik. Dan ditinjau dari sisi taksonomi siasat permukaan atau surface strategy taxonomy, kesalahan di

*Author(s) Correspondence:

E-mail: sombacute08@gmail.com 
kata kerja bantu (to be auxiliary), kata kerja beraturan (regular verb), dan kata kerja tidak beraturan (irregular verb) yang terdiri dari kesalahan misformation, misordering, omission, dan addition. Kesalahan paling tinggi di kata kerja bantu (to be auxiliary) yakni kesalahan salah formasi (misformation). Kesalahan paling tinggi di kata kerja tidak beraturan (irregular verb) yakni kesalahan salah formasi (misformation). Dan Kesalahan paling tinggi di kata kerja bantu yakni kesalahan penghilangan (Omission). Hal ini menunjukkan bahwa penggunaan simple past tense dalam menulis teks recount masih sulit dipahami peserta didik tingkat kedua Universitas Indraprasta PGRI.

Kata Kunci: simple past, teks recount

\section{INTRODUCTION}

\section{Background of Study}

Man is a social being, so instinctively human implies the identity that he brought from birth. Or in other words, humans reflect between humans or the environment one of them with the language.

Language is essentially a tool used to express thoughts or feelings by using communication symbols in the form of sounds, gestures, writings or other symbols called meaning or concepts. Since every symbol of sound has or implies a concept or meaning, it can be concluded that every speech of a language has a meaning. An example of a language symbol that reads "clothing" represents the concept or meaning of 'something commonly used by humans as the cover of the body'

W. N. Francis (1958, p. 13) defines language as an arbitrary system of articulated sounds of the society (defines language as a fluctuating system of sound articulation created and used by a group of people which means carrying on to the affairs of their community).

Language can be interpreted as a tool to convey something that comes to mind. However, language is a tool for interaction or a tool to communicate, in the sense of a tool for conveying thoughts, ideas, concepts or feelings. In sociolinguistic studies, language is defined as a symbolic system, in the form of sound, arbitrary, productive, dynamic, diverse and humane (Chaer \& Agustina, 2010, p. 11).

For the sociolinguistic concept that language is a tool or function to convey the mind is considered too narrow, because the sociolinguistic problem is "who speak what language to whom, when and to what end."
Therefore, language functions can be seen from the point of speaker, listener, topic, code and speech message (ibid, p.15).

Each country must have its own language. The main purpose of language is to be able to interact with others and the environment. Imagine if in this world there is no single language. How can we communicate to others we may not be able to ask for help from others and force us to live on our own. Language is not just a language when we speak. Many other languages such as body language are also called language because one can understand what he is trying to convey even if he does not speak. In this world there are many different kinds of languages. And language can also undergo evolutionary change or evolution, perhaps the cause is that everyone has been speaking and there may be several languages that have been accidentally changed or have given birth to a new language from a previously non-existent word.

One of the most commonly used languages of humans in the world is English. For a long time, English which is an international language has long been a compulsory subject from elementary school to college. In fact, as if not to be outdone by the elementary level, the education level of kindergarten (TK) also took part in giving English introduction. As an observer of education and teaching English in Indonesia, the authors feel proud of all the efforts that have been achieved to help children speak English.

According to McMillan and Weyyers (2010, p. 144) "English is a language that has borrowed quite freely from other languages." The English language absorbs many languages, such as French, Latin, and German. English is a necessity in the modern era as it is

*Author(s) Correspondence:

E-mail: sombacute08@gmail.com 
today. Many benefits that make our lives better if we learn English seriously and then master it.

Alonso stated, "English as a second language (ESL) education has gained an increasingly important role in career development in science, business, and industry on the global stage."

Language learning in schools includes four language skills: listening, speaking, reading, and writing. Writing skills is an activity of delivering or disclosing a message (communication) by using written language as a tool or medium. In the opinion of Abbas (2006, p. 125), writing skills is the ability to express ideas, opinions, and feelings to others through written language. The accuracy of disclosure of ideas must be supported by the accuracy of the language used, vocabulary and grammatical and spelling use. According to Nurgiyantoro, writing or composing skills is to pour ideas into written language through sentences that are strung together and clearly so that they can be communicated to the reader successfully. In the statement of Nurgiyantoro (2001, p. 273), writing skills is one of the productive and expressive language skills used to communicate indirectly and not face-to-face with others.

Meanwhile, according to Byrne in the Haryadi and Zamzani (1996, p. 77), writing is an activity express ideas through the media language. Writing is a productive and expressive activity so the writer must have the ability to use vocabulary, grammar, and language structure.

In the process of learning English, can not be denied that the students still make many mistakes. This is similar to the opinion of Tarigan (2011, p. 126) which states "error is the side that has a defect in the speech or writing of students. This can happen because of the differences in grammar that become constraints and bias occur repeatedly." This is similar as Brown's statement (2007, p. 259) "the fact that the learners do make errors, and that the errors can be observed, analyzed, and classified to reveal something of the operating system in the learner, led to a surge of study of learners' errors, called error analysis."
Based on the reasons above, the author chose the title "An Analysis on Grammatical Errors in Students' Recount Texts (A Case Study on the Second Grade Students Indraprasta PGRI University)."

\section{Statement of Problem}

Based on the background which the writer explained, the identified problems are:

1) What kinds of mistakes do students of the Second Grade Students Faculty of Letters Indraprasta PGRI University in making recount texts?

2) What type of the most dominant errors do the Second Grade Students Faculty of Letters Indraprasta PGRI University do in making recount texts?

\section{Research Objectives}

The purpose of this research is to know what kinds of mistake are done by the Second Grade Students Faculty of Letters Indraprasta PGRI University in making recount texts. And to know what kinds of the most dominant mistake done by students of the Second Grade Students Faculty of Letters Indraprasta PGRI University.

\section{Research Significance}

This study is very useful for students to gain a broader understanding of the simple past tense structure of the text recount so that they are able to make good and correct essay in accordance with English grammatical rules. And for faculty, they can know students' difficulties through their mistake in using simple past tense structure in text recount. As for the readers or other researchers, this research can be used as reference materials to expand knowledge and develop research on the analysis of English error.

\section{THEORETICAL FRAMEWORK}

English is an International Language. Because this language is very universal and used to communicate among people around the world. We can not be separated from the English language, because this language exists everywhere. like, at the office, school, on the

\footnotetext{
*Author(s) Correspondence:

E-mail: sombacute08@gmail.com
} 
computer, the internet, even in mobile phone. From this statement we can know that English is exactly beneficial for our life. Because English allows us to develop and interact as social beings. In this case, developing means to follow the modern era of globalization. And also, in this case the interaction is where we can communicate with other people around the world. English is the language of instruction used by nations in the world as a means of communication.

English learning includes four language skills: listening, speaking, reading, and writing. Hasani (2005, p. 1) states "Writing is the activity of a person in pouring ideas, thoughts, and feelings in a logical and systematic in written form so that the message can be understood by the reader." The main function of writing is as a means of communication indirectly. Akhadiah in Hasani $(2005$, p. 3) reveals the use of writing as follows, 1) The author can recognize the ability and potential himself, 2) The author can practise in developing ideas, 3) More authors can absorb, find out, and master information relating to the topic 4) The author can be trained in organizing ideas systematically and express them explicitly, 5) The author will be able to review and assess his own ideas more objectively, 6) By writing something on paper, the author will be easier to solve the problem, that is with analyze it explicitly in a more concrete context, 7) By writing, the author is encouraged to continue to learn actively, 8) The author becomes an inventor and problem solver, not merely being a tapper of information from others, 9) With planned writing activities, the author get used to think and speak in an orderly manner as well.

In writing English there is a grammar that is applied so that learners can use English well and correctly. Grammar is a picture of how words can change their shapes and can be combined into sentences in the language. This is in accordance with Harmer's statement (2001, p. 12) that the grammar of a language is the description of the ways in which words can change their forms and can be combined into sentences in that language. One example is the simple past tense structure which is the change of the first verb form into a second verb which is caused by a change in the time statement that is from the present time changed into the past.

In writing skill, we know various kinds of essays, one of them is a recount text. A recount text is a kind of English text that retells events or experiences in the past. Sudarwati and Grace (2006, p. 30) stated, "the purpose of the text recount is to tell the reader what happened in the past through the series of events." He also added that the recount text structure is divided into 4 stages: 1) Orientation, anyone who is involved in the story, when, and where it happened, 2) Events, which tells what happened chronologically, 3 Evaluation, is comments from the author or speaker about the experience told, and 4) Reorientation, that is the conclusion of the experience told.

To create a recount text, simple past tense structure is the structure used in making it. Simple past indicates that a certain activity in the past (Azar, 2002, p. 27). Surface Strategy Taxonomy or surface pricing taxonomy is one of the classifications in language errors. According to Ellis and Trawinski (2005, p. 56) "this taxonomy classifies according to the way the surface structures are altered. This taxonomy classifies errors according to how the surface structure is altered. The types of errors included in this surface tactical taxonomy are omission, addition, misformation, and misordering."

\section{RESEARCH METHOD}

In this research, the method used by writer is qualitative descriptive method. Researchers collect data in the form of recount texts made by the students of the Second Grade Students of Indraprasta PGRI University as the object under study.

\section{Source of Data}

The data in this study are words that are combined into a phrase and arranged into a clause and then connected to a sentence in accordance with the structure and use of grammar which is then assembled into

\footnotetext{
*Author(s) Correspondence:

E-mail: sombacute08@gmail.com
} 
paragraphs then the paragraphs become student essay.

While the data source is students of the Second Grade Students of Indraprasta PGRI University as primary data, and book and internet as secondary data.

\section{Research Instrument}

There are 3 tables that used as instrument in this research:

1. Table of Common Error

\begin{tabular}{|l|l|l|}
\hline Works & $\begin{array}{l}\text { Number of } \\
\text { Sentences }\end{array}$ & $\begin{array}{l}\text { Number of } \\
\text { Errors }\end{array}$ \\
\hline 1 & & \\
\hline 2 & & \\
\hline 3 & & \\
\hline 4 & & \\
\hline 5 & & \\
$\cdot$ & & \\
\hline 20 & & \\
\hline Total & & \\
\hline
\end{tabular}

2. Table of Particular Errors

\begin{tabular}{|l|l|l|}
\hline $\begin{array}{l}\text { The } \\
\text { Errors }\end{array}$ & reconstruction & $\begin{array}{l}\text { category of } \\
\text { surface } \\
\text { structure }\end{array}$ \\
\hline & & \\
\hline & & \\
\hline
\end{tabular}

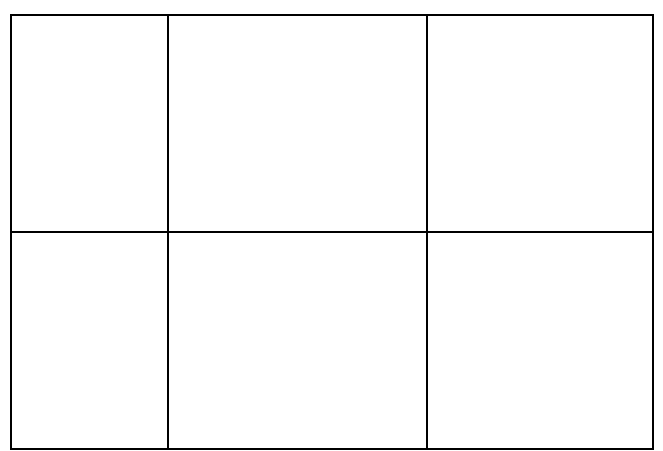

3. Table of Accumulation and Distribution

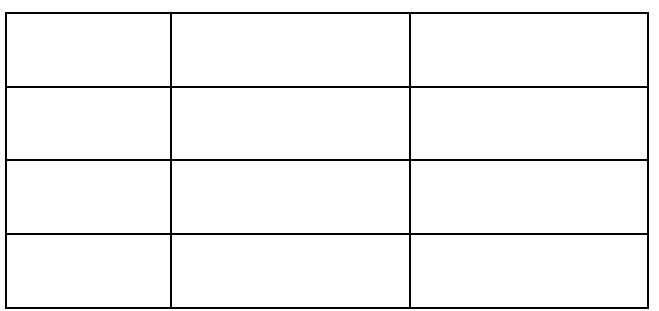

\section{Data Collection Procedures}

Below are the procedures conducted in order to collect the data:

1. Conducting observation of primary and secondary data sources.

2. The author determines the students who will be the subject of research.

3. The author describes the use of simple past structure in recount text.

4. Students are given 45 minutes to create a text recount consisting of 4 paragraphs with the theme "unforgettable moment", and the results of this test is used as the object of research.

5. Collecting students' writing.

\section{Data Analysis Procedures}

After the data collected, the next step is to perform data analysis, namely:

1) The author reads essay text recount students.

2) The author selects the data according to the indicator given.

3) The author finds errors based on error classification

4) The author classifies the error type.

*Author(s) Correspondence:

E-mail: sombacute08@gmail.com 
5) The author reconstructs and identifies the type of error.

6) The author determines the accumulation and distribution of student error by using the following formula:

$$
\mathrm{P}(\mathrm{A})=\frac{\chi}{\Sigma \mathrm{n}} \times 100 \%
$$

Information: $\mathrm{P}(\mathrm{A})=$ Percentage $X=$ Number of Errors $\sum \mathrm{n}=$ Total of Errors
7) The author determines the dominant error based on the highest percentage.

\section{RESULTS AND DISCUSSION}

After getting the data, the authors analyze the mistakes made by the students in making the recount texts.

Displayed below in Table 1 is the table which summarizes the number of Common Errors.

Table 1. Common Errors

\begin{tabular}{|c|c|c|}
\hline Works & $\begin{array}{l}\text { Number of } \\
\text { Sentences }\end{array}$ & $\begin{array}{c}\text { Number of } \\
\text { Errors }\end{array}$ \\
\hline 1 & 13 & 7 \\
\hline 2 & 10 & 4 \\
\hline 3 & 18 & 5 \\
\hline 4 & 14 & 5 \\
\hline 5 & 9 & 3 \\
\hline 6 & 19 & 4 \\
\hline 7 & 9 & 5 \\
\hline 8 & 10 & 1 \\
\hline 9 & 9 & 4 \\
\hline 10 & 9 & 2 \\
\hline 11 & 10 & 5 \\
\hline 12 & 15 & 1 \\
\hline 13 & 11 & 7 \\
\hline 14 & 10 & 7 \\
\hline 15 & 15 & 7 \\
\hline 16 & 17 & 4 \\
\hline 17 & 15 & 3 \\
\hline 18 & 12 & 4 \\
\hline 19 & 14 & 2 \\
\hline 20 & 18 & 1 \\
\hline 21 & 16 & 4 \\
\hline 22 & 9 & 4 \\
\hline 23 & 17 & 4 \\
\hline 24 & 12 & 5 \\
\hline 25 & 11 & 5 \\
\hline Total & 322 & 103 \\
\hline
\end{tabular}

Meanwhile, Table 2 displayed below summarizes the particular errors for regular verbs whereas Table 3 summarizes the particular errors for irregular verbs. Table 4 discussed the particular errors for auxiliary verbs while Table 5 contains information on the accumulation and distribution of errors.

*Author(s) Correspondence:

E-mail: sombacute08@gmail.com 
Table 2. Particular Errors for Regular Verbs

\begin{tabular}{|c|c|c|}
\hline The Errors & Reconstruction & $\begin{array}{c}\text { Category of surface } \\
\text { structure } \\
\end{array}$ \\
\hline I just wait for the order & I just waited for the order & Omission of regular verb \\
\hline I to focus on the order & I to focused on the order & Omission of regular verb \\
\hline Finally we came and join that event & $\begin{array}{l}\text { Finally we came and joined that } \\
\text { event }\end{array}$ & Omission of regular verb \\
\hline When we do not camp.... & When we did not camp.... & Misformation of regular verb \\
\hline We watching movies & We watched movies & Misformation of regular verb \\
\hline I do not care about that & I did not care about that & Misformation of regular verb \\
\hline $\begin{array}{l}\text { Miss Melani and friends visit my } \\
\text { school }\end{array}$ & $\begin{array}{l}\text { Miss Melani and friends visited } \\
\text { my school }\end{array}$ & Omission of regular verb \\
\hline We are graduated on that day & We graduated on that day & Addition of regular verb \\
\hline $\begin{array}{l}\text { We rested for a while and clean our } \\
\text { luggage }\end{array}$ & $\begin{array}{l}\text { We rested for a while and cleaned } \\
\text { our luggage }\end{array}$ & Omission of regular verb \\
\hline $\begin{array}{l}\text { After that my parents ask me to } \\
\text { avoid my friends }\end{array}$ & $\begin{array}{l}\text { After that my parents asked me to } \\
\text { avoid my friends }\end{array}$ & Omission of regular verb \\
\hline $\begin{array}{l}\text { I check my assignment before } \\
\text { having a holiday }\end{array}$ & $\begin{array}{l}\text { I checked my assignment before } \\
\text { having a holiday }\end{array}$ & Omission of regular verb \\
\hline We stop to take a rest several times & $\begin{array}{l}\text { We stopped to take a rest several } \\
\text { times }\end{array}$ & Omission of regular verb \\
\hline $\begin{array}{l}\text { I continued the trip to the villa where } \\
\text { we stay }\end{array}$ & $\begin{array}{l}\text { I continued the trip to the villa } \\
\text { where we stayad }\end{array}$ & Omission of regular verb \\
\hline I enjoy the scenery there & I enjoyed the scenery there & Omission of regular verb \\
\hline We talk in low voices & We talked in low voices & Omission of regular verb \\
\hline After 2 hours we arrive to the place & $\begin{array}{l}\text { After } 2 \text { hours we arrived to the } \\
\text { place }\end{array}$ & Omission of regular verb \\
\hline Then we move to Prambanan & Then we moved to Prambanan & Omission of regular verb \\
\hline We continue to a shop & We continued to a shop & Omission of regular verb \\
\hline And finally I achieve $1^{\text {st }}$ place & And finally I achieved $1^{\text {st }}$ place & Omission of regular verb \\
\hline We use Ringgit to do transaction & We used Ringgit to do transaction & Omission of regular verb \\
\hline After we search it,.... & After we searched it,.... & Omission of regular verb \\
\hline When I want to resume the list,... & $\begin{array}{l}\text { When I wanted to resume the } \\
\text { list,... }\end{array}$ & Omission of regular verb \\
\hline Everytime I join the race & Everytime I joined the race & Omission of regular verb \\
\hline We enjoy the dance performance & $\begin{array}{l}\text { We enjoyed the dance } \\
\text { performance }\end{array}$ & Omission of regular verb \\
\hline $\begin{array}{l}\text {.. because we want to enjoy a } \\
\text { weekend }\end{array}$ & $\begin{array}{l}\text {... because we wanted to enjoy a } \\
\text { weekend }\end{array}$ & Omission of regular verb \\
\hline We stay in "Dewa Homestay" & We stayed in "Dewa Homestay & Omission of regular verb \\
\hline
\end{tabular}

Table 3. Particular Errors for Irregular Verbs

\begin{tabular}{|l|l|l|}
\hline \multicolumn{1}{|c|}{ The Errors } & \multicolumn{1}{|c|}{ Reconstruction } & \multicolumn{1}{c|}{$\begin{array}{c}\text { Category of surface } \\
\text { structure }\end{array}$} \\
\hline So, I don't pay attention around & So, I didn't pay attention around & Misformation of regular verb \\
\hline I have to retake of al the lost cards & I had to retake of al the lost cards & Misformation of regular verb \\
\hline I and my friends was earned money & I and my friends earned money & Addition of regular verb \\
\hline 4 of my friends and I bring 3 vespas & $\begin{array}{l}\text { 4 of my friends and I brought } 3 \\
\text { vespas }\end{array}$ & Misformation of regular verb \\
\hline My family and I swim in the lake & My family and I swum in the lake & Misformation of regular verb \\
\hline
\end{tabular}

*Author(s) Correspondence:

E-mail: sombacute08@gmail.com 


\begin{tabular}{|c|c|c|}
\hline I was goes there with my aunt & I went there with my aunt & Misformation of regular verb \\
\hline Each of us has a concept & Each of us had a concept & Misformation of regular verb \\
\hline In front of office, we meet Mr. Ken & $\begin{array}{l}\text { In front of office, we met } \mathrm{Mr} \text {. } \\
\text { Ken }\end{array}$ & Misformation of regular verb \\
\hline From there, we get the certificate & From there, we got the certificate & Misformation of regular verb \\
\hline We always do anything together & We always did anything together & Misformation of regular verb \\
\hline We do the trip at 11 a.m & We did the trip at 11 a.m & Misformation of regular verb \\
\hline $\begin{array}{l}\text { After taking a break, we go back to } \\
\text { the Rendezvous }\end{array}$ & $\begin{array}{l}\text { After taking a break, we went } \\
\text { back to the Rendezvous }\end{array}$ & Misformation of regular verb \\
\hline $\begin{array}{l}\text { I and all of the students leave on } \\
\text { Saturday }\end{array}$ & $\begin{array}{l}\text { I and all of the students left on } \\
\text { Saturday }\end{array}$ & Misformation of regular verb \\
\hline $\begin{array}{l}\text { Last Friday, my friend and I have a } \\
\text { travel to mountain Pangrango }\end{array}$ & $\begin{array}{l}\text { Last Friday, my friend and I had } \\
\text { a travel to mountain Pangrango }\end{array}$ & Misformation of regular verb \\
\hline Then we take a rest & Then we took a rest & on of regular verb \\
\hline There, we see many relics of the king & $\begin{array}{l}\text { There, we saw many relics of the } \\
\text { king }\end{array}$ & Misformation of regular verb \\
\hline $\begin{array}{l}\text { We left Borobudur and go back to } \\
\text { Jakarta }\end{array}$ & $\begin{array}{l}\text { We left Borobudur and went back } \\
\text { to Jakarta }\end{array}$ & Misformation of regular verb \\
\hline Last moth I goes to Brebes & h I went to Brebes & Misformation of regular verb \\
\hline takes 7 hours & k 7 hours & Misformation of regular verb \\
\hline Many visitors come there & sitors came there & Misformation of regular verb \\
\hline $\begin{array}{l}\text { It gaves us many amazing } \\
\text { experiences }\end{array}$ & $\begin{array}{l}\text { It gave us many amazing } \\
\text { experiences }\end{array}$ & Additon of regular verb \\
\hline Our teachers lead us in front & Our teachers led us in front & Misformation of regular verb \\
\hline $\begin{array}{l}\begin{array}{l}\text { Finally our friends and I say } \\
\text { goodbye }\end{array} \\
\end{array}$ & $\begin{array}{l}\text { Finally our friends and I said } \\
\text { goodbye }\end{array}$ & Misformation of regular verb \\
\hline ited a place that we known & We visited a place that we knew & on of regular verb \\
\hline We do our activity smoothly & We did our activity smoothly & Misformation of regular verb \\
\hline $\begin{array}{l}\text { I getting some message from my } \\
\text { coach }\end{array}$ & $\begin{array}{l}\text { I got some message from my } \\
\text { coach }\end{array}$ & Misformation of regular verb \\
\hline I always get the champion & I always got the champion & Misformation of regular verb \\
\hline I get a chance to represent my school & $\begin{array}{l}\text { I got a chance to represent my } \\
\text { school }\end{array}$ & Misformation of regular verb \\
\hline I get news that really hit my heart & I got news that really hit my heart & Misformation of regular verb \\
\hline $\begin{array}{l}\text { There, we meet and talked a lot } \\
\text { about the beauty of Bali }\end{array}$ & $\begin{array}{l}\text { There, we met and talked a lot } \\
\text { about the beauty of Bali }\end{array}$ & Misformation of regular verb \\
\hline We drink coconut ice & We drank coconut ice & Misformation of regular verb \\
\hline $\begin{array}{l}\text { Last week, I choose to spend my } \\
\text { weekend at my hometown in } \\
\text { Bandung }\end{array}$ & $\begin{array}{l}\text { Last week, I chose to spend my } \\
\text { weekend at my hometown }\end{array}$ & Misformation of regular verb \\
\hline After I take a bath,... & After I took a bath,... & Misformation of regular verb \\
\hline On Tuesday, I go to college & On Tuesday, I went to college & Misformation of regular verb \\
\hline I and my family drink fresh juice & I and my family drank fresh juice & Misformation of regular verb \\
\hline
\end{tabular}

Table 4. Particular Errors for Auxiliary Verbs

\begin{tabular}{|l|l|l|}
\hline \multicolumn{1}{|c|}{ The Errors } & \multicolumn{1}{|c|}{ Reconstruction } & \multicolumn{1}{c|}{$\begin{array}{c}\text { Category of surface } \\
\text { structure }\end{array}$} \\
\hline Everything is gone & Everything was gone & Misformation of regular verb \\
\hline That is really fun & That was really fun & Misformation of regular verb \\
\hline $\begin{array}{l}\text { There is a wonderful lake outside the } \\
\text { town }\end{array}$ & $\begin{array}{l}\text { There was a wonderful lake } \\
\text { outside the town }\end{array}$ & Misformation of regular verb \\
\hline The water is fresh & The water was fresh & Misformation of regular verb \\
\hline
\end{tabular}

*Author(s) Correspondence:

E-mail: sombacute08@gmail.com 


\begin{tabular}{|c|c|c|}
\hline $\begin{array}{l}\text { The school very unique and different } \\
\text { from the usual }\end{array}$ & $\begin{array}{l}\text { The school was very unique and } \\
\text { different from the usual }\end{array}$ & Omission of regular verb \\
\hline I am proud to have a school there & I was proud to have a school there & Misformation of regular verb \\
\hline Therefore I am eager to go to school & $\begin{array}{l}\text { Therefore I was eager to go to } \\
\text { school }\end{array}$ & Misformation of regular verb \\
\hline $\begin{array}{l}\text { There are various types of goods } \\
\text { there }\end{array}$ & $\begin{array}{l}\text { There were various types of } \\
\text { goods there }\end{array}$ & Misformation of regular verb \\
\hline Halal food is easy to find & Halal food was easy to find & Misformation of regular verb \\
\hline Mr. Rio is busy making a popArt & $\begin{array}{l}\text { Mr. Rio was busy making a } \\
\text { popArt }\end{array}$ & Misformation of regular verb \\
\hline $\begin{array}{l}\text { I opened the exhibition which } \\
\text { attended by many foreigners }\end{array}$ & $\begin{array}{l}\text { I opened the exhibition which } \\
\text { was attended by many foreigners }\end{array}$ & Omission of regular verb \\
\hline $\begin{array}{l}\text { It has been exactly on the June, 12nd } \\
2016\end{array}$ & $\begin{array}{l}\text { It was exactly on the June, 12nd } \\
2016\end{array}$ & Misformation of regular verb \\
\hline $\begin{array}{l}\text { I am nervous and pleased for the } \\
\text { moment }\end{array}$ & $\begin{array}{l}\text { I was nervous and pleased for the } \\
\text { moment }\end{array}$ & Misformation of regular verb \\
\hline $\begin{array}{l}\text { Was I happy on the process of } \\
\text { graduation }\end{array}$ & $\begin{array}{l}\text { I Was happy on the process of } \\
\text { graduation }\end{array}$ & Misordering of regular verb \\
\hline I am not able to help & I was not able to help & Misformation of regular verb \\
\hline They very nice to my family & They were very nice to my family & Omission of regular verb \\
\hline The native people also friendly & $\begin{array}{l}\text { The native people were also } \\
\text { friendly }\end{array}$ & Omission of regular verb \\
\hline IWe are at post 3 & We were at post 3 & Misformation of regular verb \\
\hline We on the way & We were on the way & Misformation of regular verb \\
\hline $\begin{array}{l}\text { The destinations provided by the } \\
\text { agent }\end{array}$ & $\begin{array}{l}\text { The destinations were provided } \\
\text { by the agent }\end{array}$ & Omission of regular verb \\
\hline It is very hiring & It was very hiring & Misformation of regular verb \\
\hline I am so glad & so glad & Misformation of regular verb \\
\hline I am so very happy & I was so very happy & Misformation of regular verb \\
\hline $\begin{array}{l}\text { Nevertheless it is still an amazing } \\
\text { experience }\end{array}$ & $\begin{array}{l}\text { Nevertheless it was still an } \\
\text { amazing experience }\end{array}$ & Misformation of regular verb \\
\hline I and our peers was so excited & I and our peers were so excited & nation of regular verb \\
\hline But it is quite comfortable to us & But it was quite comfortable to us & Misformation of regular verb \\
\hline The Lumpia is very yummy & The Lumpia was very yummy & Misformation of regular verb \\
\hline I am feeling empty inside while... & $\begin{array}{l}\text { was feeling empty inside } \\
\text { while... }\end{array}$ & Misformation of regular verb \\
\hline I am very proud of this & I was very proud of this & Misformation of regular verb \\
\hline $\begin{array}{l}\text { I so excited to watch the horror } \\
\text { movie }\end{array}$ & $\begin{array}{l}\text { I was so excited to watch the } \\
\text { horror movie }\end{array}$ & Omission of regular verb \\
\hline I interested to go there & I was interested to go there & Omission of regular verb \\
\hline $\begin{array}{l}\text { There is was one expensive bird } \\
\text { inside }\end{array}$ & $\begin{array}{l}\text { There was one expensive bird } \\
\text { inside }\end{array}$ & Addition of regular verb \\
\hline When I careless & When I was careless & Omission of regular verb \\
\hline I am very happy at that time & I was very happy at that time & Misformation of regular verb \\
\hline There are many foreigners & There were many foreigners & Misformation of regular verb \\
\hline The food is so delicious & The food was so delicious & Misformation of regular verb \\
\hline We very happy & We were very happy & Omission of regular verb \\
\hline $\begin{array}{l}\text { The homestay is located not far from } \\
\text { Malioboro street }\end{array}$ & $\begin{array}{l}\text { The homestay was located not far } \\
\text { from Malioboro street }\end{array}$ & Misformation of regular verb \\
\hline I am very excited & I was very excited & Misformation of regular verb \\
\hline
\end{tabular}

*Author(s) Correspondence:

E-mail: sombacute08@gmail.com 
Table 5. Accumulation and Distribution of Errors

\begin{tabular}{|c|c|c|c|c|c|c|c|c|c|c|c|c|c|c|c|c|c|c|c|c|c|c|c|c|c|c|c|}
\hline Type of & \multicolumn{25}{|c|}{ Table of Accumulation and Distribution } & \multicolumn{2}{|c|}{ Total } \\
\hline Error & 1 & 2 & 3 & 4 & 5 & 6 & 7 & 8 & 9 & 10 & 11 & 12 & 13 & 14 & 15 & 16 & 17 & 18 & 19 & 20 & 21 & 22 & 23 & 2 & 2 & & $\%$ \\
\hline $\begin{array}{c}\text { Regular } \\
\text { Verb }\end{array}$ & 3 & 1 & 2 & 1 & 1 & 1 & 1 & - & 1 & 1 & - & 1 & 2 & 1 & 3 & 1 & 2 & 1 & 1 & - & 1 & 1 & 1 & - & 2 & & $\begin{array}{l}29 . \\
87\end{array}$ \\
\hline $\begin{array}{c}\text { Irregular } \\
\text { Verb }\end{array}$ & 2 & 2 & 1 & 1 & - & 1 & - & - & 2 & 1 & 2 & - & 4 & 3 & 2 & 2 & - & 1 & - & - & 1 & 2 & 2 & 4 & - & & $\begin{array}{l}33 . \\
90\end{array}$ \\
\hline $\begin{array}{c}\text { To be } \\
\text { Auxiliary }\end{array}$ & 2 & 1 & 2 & 3 & 2 & 2 & 4 & 1 & 1 & - & 3 & - & 1 & 3 & 2 & 1 & 1 & 2 & 1 & 1 & 2 & 1 & 1 & 1 & 3 & & $\begin{array}{l}42 . \\
23\end{array}$ \\
\hline & 6 & 4 & 5 & 5 & 3 & 4 & 5 & 1 & 4 & 2 & 5 & 1 & 7 & 7 & 7 & 4 & 3 & 4 & 2 & 1 & 4 & 4 & 4 & 5 & 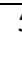 & & $\begin{array}{c}\mathbf{1 0} \\
\mathbf{0}\end{array}$ \\
\hline
\end{tabular}

Figure 1 below summarizes the percentage of errors committed by the students when they were using simple past tense in recount text.

Figure 1. Percentage of errors on using simple past in recount text

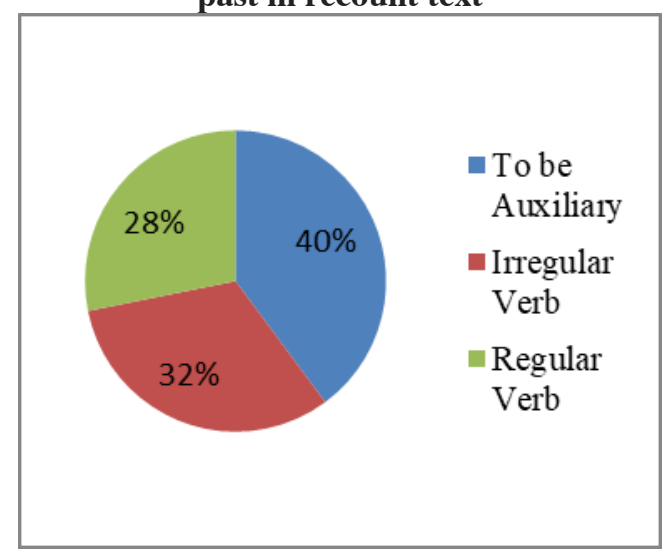

\section{CONCLUSION}

Based on the results of data analysis and research on students of the Second Grade Students Faculty of Letters Indraprasta PGRI University, the author get the conclusion that there is an error in the use of simple past tense structure in text recount consisting of errors in the use of regular verb, irregular verb, and to be auxiliary.

The result of the error analysis process is that learners perform three types of errors which are regular verb, irregular verbs, and auxiliary verbs. It is seen from the percentage of each type of error, the auxiliary verb is the most commonly performed error type with a percentage of $42,23 \%$. Furthermore, errors in irregular verb is $33,90 \%$, whereas the type of regular verb error is $29,87 \%$ of the total errors made by the learner. And from the side of the taxonomy of surface tactics or surface strategy taxonomy, errors in regular verb, irregular verb, and to be auxiliary consist of misformation, misordering, omission, and addition error. The highest error on auxiliary verb is misformation. The highest error on irregular verb is misformation. And the highest error in regular verb is omission. This shows that the use of simple past tense in writing recount text is still difficult to understand the students of the second grade of PGRI Indraprasta University.

In an effort to improve students' understanding of the use of simple past tense structures in writing text recounts, teachers should give students more attention in teaching them to make recount texts by using simple past tense structures. Then the teacher should often provide practice to students so that students understand and able to write essays properly and correctly.

For students, students should do a lot of practice and more thoroughly in using simple past tense structure in making recount texts.

\section{REFERENCES}

Abbas, S. (2006.) Pembelajaran Bahasa Indonesia yang efektif di sekolah dasar. Jakarta: Departemen Pendidikan Nasional.

Azar, B. S. (2002). Understanding and using English grammar (3 ${ }^{\text {rd }}$ Edition). New York: Pearson Education.

*Author(s) Correspondence:

E-mail: sombacute08@gmail.com 
Brown, H. D. (2007). Principles of language learning and teaching ( $5^{\text {th }}$ Edition). New York: Pearson Education.

Chaer, A., \& Agustina, L. (2010). Sosiolinguistik: Perkenalan awal. Jakarta: Rineka Cipta.

Francis, W. N. (1958). The structure of American English. New York: Ronald Press Company.

Harmer, J. (2001). The practice of English language teaching $\left(3^{\text {rd }}\right.$ Edition $)$. London: Longman.

Haryadi \& Zamzani. (1996). Peningkatan keterampilan berbahasa Indonesia. Yogyakarta: Depdikbud.
Hasani, A. (2005). Ihwal menulis. Serang: Untirta Pers.

McMillan, K., \& Weyyers, J. (2010). How to write essays and assignments. London: Pearson Education Limited.

Nurgiyantoro, B. (2001). Menulis secara populer. Jakarta: Pustaka Jaya.

Sudarwati, T. M., \& Grace, E. (2007). Look ahead: An English course for senior high school students year X. Jakarta: Erlangga.

Tarigan, H. G. (2011). Pengajaran analisis kesalahan berbahasa. Bandung: Angkasa.

*Author(s) Correspondence:

E-mail: sombacute08@gmail.com 